\title{
EFEKTIVITAS PENEGAKAN HUKUM TERHADAP PEJALAN KAKI (PEDESTRIAN) DALAM PERKARA KECELAKAAN LALU LINTAS
}

\author{
oleh: \\ R. Nurul Nurachman \\ Dudu Duswara Machmudin
}

\begin{abstract}
ABSTRAK
Penulis tertarik mengkaji judul ini karena antara praktik dan aturan terdapat kesenjangan yang sangat tajam terutama dalam Pasal 310 dan Pasal 311 Undang-undang Republik Indonesia Nomor 22 Tahun 2009 Tentang Lalu Lintas dan Angkutan Jalan. Kedua pasal tersebut mengarahkan pada faktor pengemudi sebagai penyebab terjadinya kecelakaan, padahal banyak sekali perkara kecelakaan lalu lintas yang penyebab kecelakaan di akibatkan oleh pengguna jalan lain yaitu pejalan kaki yang menyebrang jalan tanpa memperhatikan keselamatan dan mengganggu fungsi jalan sehingga terjadilah kecelakaan, sedangkan aparat penegak hukum karena sulit menetapkan saksi dan bukti dan aturan Pasal 310 dan 311 Undang Undang Republik Indonesia Tentang Lalu Lintas Angkutan Jalan menekankan pengemudi kendaraan bermotor merupakan objek yang akan dikriminalisasikan, Dari latar belakang tersebut, penulis merumuskan identifikasi masalahnya adalah Apakah pidana bagi pejalan kaki dalam perkara kecelakaan lalu lintas berdasarkan Undang-undang Republik Indonesia Nomor 22 tahun 2009 tentang Lalu Lintas dan Angkutan Jalan ? dan Bagaimanakah penerapan Unsur Efektivitas Penegakan Hukum terhadap Pejalan Kaki dalam Perkara Kecelakaan Lalu lintas menurut Menurut Undang-undang Republik Indonesia Nomor 22 Tahun 2009 tentang Lalu Lintas dan Angkutan Jalan ? Penyidik kepolisian dalam melakukan investigasi alat bukti perkara kecelakaan lalu lintas dengan objek terperiksa pedestrian lalai dalam kondisi menyeberang jalan, menurut norma tentang penetapan dan pembatalan, tindakan pedestrian yang kelalaian dalam menyeberang jalan yang bebas dari sistem moralitas dan norma sejenis lainnya. Hal ini membedakan antara hukum pidana dengan norma etika berlalu lintas dianggap sebagai pelanggaran, baik itu melanggar norma berprilaku (etika) atau norma kebiasaan berlalu lintas di suatu daerah. Ketika pedestrian lalai maka, kelalaian tersebut bukan merupakan suatu perbuatan pidana (straafbaarfeit), melainkan berada dalam ranah etika kebiasaan yang tidak mengindahkan atau mengutamakan keselamatan berlalu lintas. Penerapan unsur efektivitas penegakan hukum terhadap pejalan kaki dalam perkara kecelakaan lalu lintas dapat dilakukan kepolisian, namun terkendala dalam proses investigasi dalam mencari alat bukti, terutama barang bukti, saksi dapat diperoleh
\end{abstract}

\section{PENDAHULUAN}

\section{A. Latar Belakang}

Salah satu masalah yang muncul dalam penanganan laka lantas adalah munculnya pemikiran mengenai benar atau salah berdasarkan pada logika sederhana, seperti apabila terjadi kecelakaan antara sepeda motor menabrak pejalan kaki, maka pastilah si pengendara sepeda motor adalah pihak yang bersalah. Atau apabila terjadi tabrakan antara pengemudi roda empat dengan roda dua maka pastilah pengemudi roda empat sebagai pihak yang lalai.Kesimpulan sementara berdasarkan pengamatan seringkali memunculkan kekeliruan dalam membuktikan siapa pihak yang bersalah dalam sebuah laka lantas ${ }^{1}$.

\footnotetext{
${ }^{1}$ https://ferli1982.wordpress.com/2013/10/18/pembuktian-ilmiah-dalam-penanganan-laka-lantas/ diunduh pada tanggal 8 Oktober 2016 pada pukul 21.45
} 
Budaya lalu lintas seperti yang telah dijelaskan di atas memacu penyidik kepolisian untuk bekerja lebih professional, tindakan yang pertama dilakukan adalah dengan melakukan pengolahan tempat kejadian perkara (olah TKP), yaitu mencari, mengumpulkan, menganalisis, mengevaluasi petunjuk-petunjuk, keterangan-keterangan, bukti-bukti, serta identitas tersangka, guna memberi arah kepada penyidikan ${ }^{2}$,namun metode penyidikan pada tahapolah TKP kecelakaan lalu lintas saat ini masih dilakukan secara manual, tindakan pendahuluan yang dilakukan oleh penyidik laka lantas adalah sebagai berikut ${ }^{3}$ :

1. Pemotretan TKP laka lantas,

2. Pembuatan sketsa TKP laka lantas kedalam gambar manual, kemudian,

3. Membuat berita acara pemeriksaan sesuai dengan ketentuan yang bersangkutan.

Olah TKP diatas telah menimbulkan suatu pertanyaan besar bagi pilar penegakan hukum dalam menangani kasus kecelakaan lalu lintas di Indonesia.Pertanyaannya adalah bagaimana kebenaran dari pemeriksaan pendahuluan yang dicari dan diwujudkan dalam perkara kecelakaan lalu lintas, harus diyakini hakim sebagai kebenaran materil. Prinsip inilah yang disebut beyond reasonable doubt atau kebenaran yang diwujudkan benar-benar berdasarkan bukti-bukti yang tidak meragukan, sehingga kebenaran itu dianggap bernilai sebagai kebenaran hakiki.

Pasal 132 Undang-undang Republik Indonesia Nomor 22 Tahun 2009 Tentang Lalu Lintas Angkutan Jalan mengatur juga mengenai Kewajiban kaki wajib Menggunakan bagian Jalan yang diperuntukkan bagi pejalan kaki atau jalan yang paling tepid an Menyeberang di tempat yang telah ditentukan, Dalam hal tidak terdapat tempat penyeberangan yang ditentukan sebagaimana dimaksud pada Ayat 1 Huruf $b$, pejalan kaki wajib memperhatikan keselamatan dan kelancaran lalu lintasPejalan kaki penyandang cacat harus mengenakan tanda khusus yang jelas dan mudah dikenali pengguna jalan lain.

Pejalan kaki menurut Undang Undang Republik Indonesia Nomor 22 Tahun 2009 tentang Lalu Lintas dan Angkutan Jalan harus diprioritaskan, unsur diprioritaskan adalah ketika pengendara lain dengan jarak pandang atau objek prioritas atau berada dalam situasi kondisi selamat. pejalan kaki (pedestrian) pengguna jalan mendapat prioritas dalam hukum. Namun apalah artinya jika pedestrian mengabaikan prioritas yang diberikan oleh undangundang tersebut.

\section{Identifikasi Masalah}

Penulis tertarik mengangkat permasalahan antara praktik dan aturan terdapat kesenjangan yang sangat tajam terutama dalam Pasal 310 dan Pasal 311 Undang-undang Republik Indonesia Nomor 22 Tahun 2009 Tentang Lalu Lintas dan Angkutan Jalan. Kedua pasal tersebut mengarahkan pada faktor pengemudi sebagai penyebab terjadinya kecelakaan

\section{TINJAUAN PUSTAKA}

\section{A. Pejalan Kaki (Pedestrian).}

Pejalan kaki adalah orang yang melakukan aktivitas berjalan kaki dan merupakan salah satu unsur pengguna jalan. (Keputusan Direktur Jendral Perhubungan Darat : SK.43/AJ 007/DRJD/97). Pejalan kaki harus berjalan pada bagian jalan yang diperuntukan bagi pejalan kaki, atau pada bagian pejalan kaki, atau pada bagian jalan yang paling kiri apabila

\footnotetext{
${ }^{2}$ Peraturan Kapolri Republik Indonesia No 6 Tahun 2010 Tentang Manajemen Penyidikan oleh Pegawai Negeri Sipil.

${ }^{3}$ Wawancara dengan penyidik lakalantas Kota Bogor
} 
tidak terdapat bagian jalan yang diperuntukan bagi pejalan kaki. Keragaman Pejalan Kaki Penyeberang jalan dengan kondisi fisik yang mendapat perhatian khusus dapat dibagi menjadi 3 yaitu :

1. Penyeberang yang cacat fisik Adalah pengguna jalan/penyeberang yang cacat fisiknya atau mempunyai keterbatasan fisiknya, oleh karena itu perlu diberikan fasilitas khusus.

2. Penyeberang anak-anak Adalah penyeberang pada usia anak-anak (0-12 tahun) yang sering 7 terjadi kecelakaan dibanding dengan golongan lainnya.

3. Penyeberang usia lanjut Penyeberang usia lanjut lebih cenderung mengalami kecelakaan daripada usia yang lainnya disebabkan oleh :

a. Kelemahan fisik

b. Membutuhkan waktu yang lebih lama untuk menyeberang ( karena faktor usia).

c. Perilaku Pejalan Kaki Karateristik pejalan kaki menurut Shane dan Roess (1990) secara umum meliputi :

1) Volume pejalan kaki v (pejalan kaki/menit/meter)

2) Kecepatan menyeberang $\mathrm{S}$ (meter/menit)

3) Kepadatan D (pejalan kaki/meter persegi).

\section{B. Pengertian Fasilitas Penyeberangan}

Pada hakikatnya, aktivitas pejalan kaki bertujuan untuk menempuh jarak sesingkat mungkin antara satu tempat dengan tempat lain dengan nyaman dan aman dari gangguan. Maka dibutuhkan sarana tersebut yaitu fasilitas penyeberangan. Fasilitas penyeberangan adalah fasilitas pejalan kaki untuk menyeberang jalan. (Keputusan Direktur Jendral Perhubungan Darat : SK.43/AJ 007/DRJD/97). Fasilitas penyeberangan dibagi dalam 2 kelompok tingkatan yaitu 4

1. Penyeberangan Sebidang (At-Grade) Penyeberangan sebidang terdiri atas 2 macam yaitu :

a. Penyeberangan Zebra Cross adalah fasilitas penyeberangan yang ditandai dengan garisgaris berwarna putih searah arus kendaraan dan dibatasi garis melintang lebar jalan. Zebra cross ditempatkan di jalan dengan jumlah aliran penyeberang jalan atau arus yang relatif rendah sehingga penyeberang masih mudah memperoleh kesempatan yang aman untuk menyeberang. Persyaratan penggunaan Zebra Cross antara lain :

1) Dipasang dikaki persimpangan tanpa alat pemberi isyarat lalu lintas atau diruas jalan.

2) Apabila persimpangan diatur dengan lampu pengatur lalu lintas, pemberian waktu penyeberangan bagi pejalan kaki menjadi satu kesatuan dengan lampu pengatur lalu lintas persimpangan.

3) Apabila persimpangan tidak diatur dengan lampu pengatur lalu lintas, maka kriteria batas kecepatan kendaraan bermotor adalah $<40 \mathrm{~km} / \mathrm{jam}$.

2. Penyeberangan Pelican adalah Zebra Cross yang dilengkapi dengan lampu pengatur bagi penyeberang jalan dan kendaraan. Fase berjalan bagi penyeberang jalan dihasilkan dengan menekan tombol pengatur dengan lama periode berjalan yang telah ditentukan Fasilitas ini bermaanfaat bila ditempatkan di jalan dengan arus penyeberang jalan yang tinggi. Penggunaan dari Pelikan dengan syarat dipasang pada ruas jalan, minimal 300 meter dari persimpangan, atau. Pada jalan dengan kecepatan operasional rata-rata lalu lintas kendaraan $>40 \mathrm{~km} / \mathrm{jam}$.

${ }^{4}$ Dirjen Penataan Ruang, Pedoman Penyediaan dan Pemanfaatan Prasarana dan Sarana Ruang Pejalan Kaki di Perkotaan, 2000 
3. Penyeberangan Tidak Sebidang (Elevated/Underground) Penyeberangan tidak sebidang terdiri atas 2 kategori yaitu :

a. Elevated/Jembatan Adalah adalah jembatan yang dibuat khusus bagi para pejalan kaki. Fasilitas ini bermaanfaat jika ditempatkan di jalan dengan arus penyeberang jalan dan kendaraan yang tinggi, khususnya pada jalan dengan arus kendaraan berkecepatan tinggi. Jembatan penyeberangan akan dapat berfungsi dengan baik apabila bangunannya landai atau tidak terlalu curam. Jembatan penyeberangan dapat membantu mengurangi kemacetan arus lalu lintas yang salah satu penyebab adalah banyaknya orang yang menyeberang di jalan. Persyaratan penggunaan jembatan penyeberangan antara lain :

1) Jenis/jalur penyeberangan tidak dapat menggunakan penyeberangan.

2) Pelikan sudah mengganggu lalu lintas kendaraan yang ada.

3) Pada ruas jalan dengan frekuensi terjadinya kecehlakaan pejalan kaki yang cukup tinggi.

b. Jembatan penyeberangan pejalan kaki adalah jembatan yang hanya diperuntukan bagi lalu lintas pejalan kaki yang melintas diatas jalan raya atau jalan kereta api. ${ }^{5}$

c. Underground/Terowongan Sama halnya dengan jembatan penyeberangan, namun pembangunan terowongan dilakukan dibawah tanah. Pembuatan terowongan bawah tanah untuk penyeberangan membutuhkan perencanaan yang lebih rumit dan lebih mahal dari pada pembuatan jembatan penyeberangan, namun sistem terowongan ini lebih indah karena bisa dapat menjaga kebersihan dan keindahan lingkungan. Underground/terowongan digunakan apabila :

1) Jenis jalur penyeberangan dengan menggunakan elevated/jembatan tidak dimungkinkan untuk diadakan.

2) Lokasi lahan/medan memungkinkan untuk dibangun underground/terowongan.

\section{Unsur Tindak Pidana Kecelakaan Lalu lintas.}

Sebelum terjadinya suatu tindak pidana kecelakaan lalu lintas, penulis membahas teori dari tindak pidana itu sendiri, bahwa tindak pidana Menurut Moeljatno pada dasarnya tindak pidana merupakan suatu pengertian dasar dalam hukum pidana. Tindak pidana adalah suatu pengertian yuridis seperti halnya untuk memberikan definisi atau pengertian terhadap istilah hukum, maka bukanlah hal yang mudah untuk memberikan definisi atau pengertian terhadap istilah tindak pidana. Pembahasan hukum pidana dimaksudkan untuk memahami pengertian pidana sebagai sanksi atas delik, sedangkan pemidanaan berkaitan dengan dasar-dasar pembenaran pengenaan pidana serta teori-teori tentang tujuan pemidanaan. Perlu disampaikan di sini bahwa, pidana adalah merupakan suatu istilah yuridis yang mempunyai arti khusus sebagai terjemahan dari bahasa Belanda "straf" yang dapat diartikan sebagai "hukuman"6

Kecelakaan adalah serangkaian peristiwa dari kejadian, yang tidak diduga sebelumnya, dan selalu mengakibatkan kerusakan benda, luka, atau kematian. Lalu Lintas adalah gerak kendaraan dan orang di ruang lalu lintas jalan. Kecelakaan lalu lintas adalah suatu peristiwa di jalan yang tidak diduga dan tidak disengaja melibatkan kendaraan

\footnotetext{
${ }_{5}^{5}$ Dirjen Bina Marga,Tata Cara Perencanaan Jembatan Penyeberangan Untuk Pejalan Kaki di Perkotaan, 1995

${ }^{6}$ Moeljatno, Asas-asas Hukum Pidana. Bina Aksara, Jakarta, 1987, hlm. 37
} 
dengan atau tanpa pengguna jalan lain yang mengakibatkan korban manusia dan / atau kerugian harta benda ${ }^{7}$

Ketidak patuhan terhadap norma hukum bisa mengakibatkan timbulnya kesalahan seperti dalam peristiwa kecelakaan lalu lintas, kecelakaan lalu lintas merupakan kesalahan yang dibuat oleh manusia sendiri selain dari aspek kendaraan dan jalan. Kesalahan yang tidak disengaja atau lebih dikarenakan oleh tindakan kelalaian berlalu lintas biasa terjadi padahal tidak menuntut kemungkinan kesengajaan pengemudi bisa saja terjadi, sehingga tidak ada kekhilafan dari hakim dalam memutuskan suatu perkara mengenai tindak pidana terhadap sebuah kesalahan.

Masalah yang dihadapi dewasa ini adalah makin tingginya angka kecelakaan lalu lintas di jalan raya, memperhatikan hal tersebut di atas, perlu diketahui apakah ketentuan perundang-undangan yang berlaku saat ini telah cukup memberi keadilan. Apalagi Jika mencermati dalam Undang-undang khusus yang mengatur tentang lalu lintas yaitu Undang -undang Nomor 22 Tahun 2009 Tentang Lalu lintas dan Angkutan Jalan belum mengatur adanya mengenai pengemudi dalam keadaan-keadan misalnya dalam keadaan mabuk pengaruh minuman keras atau obat-obatan sehingga kelalaian dan kesengajaan sangat sulit untuk dirumuskan menjadi sebuah kepastian dalam kecelakaan lalu lintas sehingga kepastian hukum tidak tercapai tujuannya. Hal ini berkaitan dengan permasalahan seputar pertanggung jawaban pengemudi dalam suatu kecelakaan lalu lintas dimana selain disebabkan oleh kelalaian seorang pengemudi, ada faktor lain yang lebih besar dari pada faktor kelalaian jika diperhatikan hal tersebut yaitu jika mengemudi seperti dalam keadaan mabuk karna alkohol atau obat-obatan, kelelahan, berkendara melebihi batas kecepatan. Risiko mengemudi dalam keadan tersebut diabaikan sehingga kesalahan dalam bentuk kesengajaan menurut hukum bisa saja terjadi.

Kelalaian yang menyebabkan terjadinya kecelakaan lalu lintas hingga mengakibatkan orang lain meninggal dunia yang disebabkan oleh kesalahan pengemudi kendaraan biasa menjadi perdebatan para pakar hukum dalam penerapan unsur delik, Hal ini terjadi karena faktor kelalaian atau kehilafan dari hakim dalam memutuskan suatu perkara, sehingga sangat merugikan pihak tertentu dan akibatnya melenceng dari tujuan hukum. Bahkan yang telah menjadi Yurispundensi kasus kecelakaan lalu lintas dijadikan kembali sebagai bahan kajian hukum, sebab kebiasaan hakim sering kali melakukan kekeliruan terhadap para terdakwa karena tipisnya perbedaan antara kelalaian dan kesengajaan terhadap kecelakaan lalu lintas.Menurut doktrin, unsur-unsur delik terdiri atas unsur unsur subjektif dan unsur objektif. ${ }^{8}$ Terhadap unsur-unsur tersebut dapat diutarakan sebagai Unsur subjektif,

Unsur subjektif adalah unsur yang berasal dari dalam diri pelaku. Asas pidana menyatakan "tidak ada hukuman kalau tidak ada kesalahan

"An act does not make a person guilty unless the mind is guilty or actus non facit reum nisi means sit rea"

Kesalahan yang dimaksud disini adalah yang diakibatkan oleh kesengajaan (intention / opzet / dolos) dan kealpaan (negligence or schuld), adapun unsur subjektif terdiri dari:

\section{Efektivitas Penegakan Hukum}

Salah satu fungsi hukum, baik sebagai kaidah maupun sebagai sikap atau perilaku adalah membimbing perilaku manusia. Masalah pengaruh hukum tidak hanya terbatas pada timbulnya ketaatan atau kepatuhan pada hukum, tapi mencakup efek total dari hukum terhadap sikap tindak atau perilaku baik yang bersifat positif maupun negatif. Efektivitas

\footnotetext{
7 TRL-UK/Institute of Road Engineering, 1997, Accident Costs in Indonesia. Road Research Development Project, Report No. RRDP 17, Agency for Research and Development, Bandung, Indonesia, hlm. 2

${ }^{8}$ Leden Marpaung, Asas - Teori - Praktik Hukum Pidana, Sinar Grafika, Jakarta, 2009, hlm,9.
} 
penegakan hukum sangat berkaitan erat dengan efektivitas hukum. Agar hukum itu efektif, maka diperlukan aparat penegak hukum untuk menegakkan sanksi tersebut. Suatu sanksi dapat diaktualisasikan kepada masyarakat dalam bentuk ketaatan (compliance), dengan kondisi tersebut menunjukkan adanya indikator bahwa hukum tersebut adalah efektif. Faktor-faktor yang memengaruhi efektivitas hukum menurut Soerjono Soekanto antara lain sebagai berikut ${ }^{9}$

\section{Faktor Hukum}

Hukum mengandung unsur keadilan, kepastian dan kemanfaatan. Dalam praktik penerapannya tidak jarang terjadi pertentangan antara kepastian hukum dan keadilan. Kepastian Hukum sifatnya konkret berwujud nyata, sedangkan keadilan bersifat abstrak sehingga ketika seseorang hakim memutuskan suatu perkara secara penerapan undang-undang saja, maka ada kalanya nilai keadilan itu tidak tercapai. Maka, ketika melihat suatu permasalahan mengenai hukum setidaknya keadilan menjadi prioritas utama. Karena hukum tidak semata-mata dilihat dari sudut hukum tertulis saja, melainkan juga ikut mempertimbangkan faktor-faktor lain yang berkembang dalam masyarakat. Sementara dari sisi lain, keadilan pun masih menjadi perdebatan disebabkan keadilan mengandung unsur subyektif yang sangat tergantung pada nilai-nilai intrinsik subyektif dari masing-masing orang.

\section{Faktor Penegak Hukum}

Penegakan hukum berkaitan dengan pihak-pihak yang membentuk maupun menerapkan hukum (law enforcement). Bagian-bagian law enforcement itu adalah aparatur penegak hukum yang mampu memberikan kepastian, keadilan, dan kemanfaatan hukum secara proporsional. Aparatur penegak hukum melingkupi pengertian mengenai institusi penegak hukum dan aparat penegak hukum, sedangkan aparat penegak hukum dalam arti sempit dimulai dari kepolisian, kejaksaan, kehakiman, penasehat hukum dan petugas sipir lembaga pemasyarakatan. Setiap aparat dan aparatur diberikan kewenangan dalam melaksanakan tugasnya masingmasing yang meliputi kegiatan penerimaan laporan, penyelidikan, penyidikan, penuntutan, pembuktian, penjatuhan vonis dan pemberian sanksi serta upaya pembinaan kembali terpidana Ada tiga elemen penting yang memengaruhi mekanisme bekerjanya aparat dan aparatur penegak hukum, antara lain:

a. institusi penegak hukum beserta berbagai perangkat sarana dan prasarana pendukung dan mekanisme kerja kelembagaannya;

b. budaya kerja yang terkait dengan aparatnya, termasuk mengenai kesejahteraan aparatnya

C. perangkat peraturan yang mendukung baik kinerja kelembagaanya maupun yang mengatur materi hukum yang dijadikan standar kerja, baik hukum materiilnya maupun hukum acaranya. Upaya penegakan hukum secara sistematik haruslah memperhatikan ketiga aspek itu secara simultan, sehingga proses penegakan hukum dan keadilan secara internal dapat diwujudkan secara nyata.

\section{Faktor Sarana atau Fasilitas Hukum}

Fasilitas pendukung secara sederhana dapat dirumuskan sebagai sarana untuk mencapai tujuan. Ruang lingkupnya terutama adalah sarana fisik yang berfungsi

\footnotetext{
${ }^{9}$ Soerjono Soekanto, Pokok-pokok Sosiologi Hukum, PT Raja Grafindo Persada, Jakarta 2007, 110
} 
sebagai faktor pendukung. Fasilitas pendukung mencakup tenaga manusia yang berpendidikan dan terampil, organisasi yang baik, peralatan yang memadai, keuangan yang cukup, dan sebagainya. Selain ketersediaan fasilitas, pemeliharaan pun sangat penting demi menjaga keberlangsungan. Sering terjadi bahwa suatu peraturan sudah difungsikan, padahal fasilitasnya belum tersedia lengkap. Kondisi semacam ini hanya akan menyebabkan kontra-produktif yang harusnya memperlancar proses justru mengakibatkan terjadinya kemacetan.

\section{Faktor Masyarakat}

Penegakan hukum bertujuan untuk mencapai kedamaian dalam masyarakat. Masyarakat mempunyai pendapat-pendapat tertentu mengenai hukum. Artinya, efektivitas hukum juga bergantung pada kemauan dan kesadaran hukum masyarakat. Kesadaran yang rendah dari masyarakat akan mempersulit penegakan hukum, adapun langkah yang bisa dilakukan adalah sosialisasi dengan melibatkan lapisan-lapisan sosial, pemegang kekuasaan dan penegak hukum itu sendiri. Perumusan hukum juga harus memerhatikan hubungan antara perubahan-perubahan sosial dengan hukum yang pada akhirnya hukum bisa efektif sebagai sarana pengatur perilaku masyarakat.

\section{Faktor Kebudayaan}

Faktor kebudayaan yang sebenarnya bersatu padu dengan faktor masyarakat sengaja dibedakan, karena di dalam pembahasannya diketengahkan masalah sistem nilai-nilai yang menjadi inti dari kebudayaan spiritual atau nonmaterial. Hal ini dibedakan sebab sebagai suatu sistem (atau sub system dari sistem kemasyarakatan), maka hukum mencakup, struktur, subtansi, dan kebudayaan. Struktur mencangkup wadah atau bentuk dari system tersebut, umpamanya, menyangkup tatanan lembagalembaga hukum formal, hukum antara lembaga-lembaga tersebut, hak-hak dan kewajiban- kewajibanya, dan seterusnya Hukum mempunyai pengaruh langsung atau pengaruh yang tidak langsung di dalam mendorong terjadinya perubahan sosial. Caracara untuk memengaruhi masyarakat dengan sistem yang teratur dan direncanakan terlebih dahulu dinamakan social engineering atau social planning ${ }^{10}$ Agar hukum benar-benar dapat memengaruhi perlakuan masyarakat, maka hukum harus disebarluaskan, sehingga melembaga dalam masyarakat. Adanya alat-alat komunikasi tertentu merupakan salah satu syarat bagi penyebaran serta pelembagaan hukum. Komunikasi hukum tersebut dapat dilakukan secara formal yaitu, melalui suatu tata cara yang terorganisasi dengan resmi.

Soerjono Soekanto menjelaskan bahwa suatu sikap tindak perilaku hukum dianggap efektif, apabila sikap, tindakan atau perilaku lain menuju pada tujuan yang dikehendaki, artinya apabila pihak lain tersebut mematuhi hukum. Undang-undang dapat menjadi efektif jika peranan yang dilakukan pejabat penegak hukum semakin mendekati apa yang diharapkan oleh undang-undang dan sebaliknya menjadi tidak efektif jika peranan yang dilakukan oleh penegak hukum jauh dari apa yang diharapkan undang- undang. ${ }^{11}$

\footnotetext{
${ }^{10}$ Soerjono Soekanto, Kesadaran Hukum dan Kepatuhan Hukum, Rajawali Pers, Jakarta 1982,hlm,115

${ }^{11}$ Soerjono Soekanto, Faktor-faktor yang Memengaruhi Penegakan Hukum ,PT Raja Grafindo Persada, Jakarta, 2005,hlm, 9
} 


\section{PEMBAHASAN}

\section{Pejalan Kaki Tidak Dapat Dipidana dalam Perkara Tindak Pidana Kecelakaan Lalu Lintas}

Penyidik kepolisian dalam melakukan investigasi alat bukti perkara kecelakaan lalu lintas dengan objek terperiksa pedestrian dalam kondisi menyeberang jalan, pedestrianmenurut norma dasar suatu tata aturan hukum dipostulasikan sebagai aturan akhir tentang penetapan dan pembatalan, fakta hukum dibuat dan dibatalkan dengan tindakan pedestrian yang menyeberang jalan yang bebas dari sistem moralitas dan norma sejenis lainnya. Hal ini membedakan antara hukum pidana dengan norma etika berlalu lintas dianggap sebagai pelanggaran, baik itu melanggar norma berprilaku (etika) atau norma kebiasaan berlalu lintas di suatu daerah.

Bahwa kekuatan pembuktian dan unsur pidana pada pedestrian yang menyeberang jalan, pada dasarnya saling berkaitan satu sama lainnya, artinya satu alat bukti saja tidak cukup (Unus testis nullus testis), dibutuhkan kesesuaian alat bukti lain untuk mencari suatu kebenaran materil. kekuatan alat bukti Pasal 184 KUHAP tergantung pada penafsiran hakim dalam menerima alat bukti yang dihadirkan jaksa dan tergantung penafsiran hakim dalam mempertimbangkan alat bukti dalam Pasal 184 KUHAP tersebut.

Analisa Pasal 184 KUHAP dalam menerapkan unsur pidana pada pedestrian yang lalai pada saat menyeberang jalan dilaporkan kedalam suatu bentuk keterangan saksi, sebagai suatu contoh saksi yang dihadirkan oleh jaksa penuntut umum menerangkan bahwa dalam perkara kecelakaan lalu lintas pedestrian yang berupaya menabrakan diri pada bus di Ciamis, bahwa dari arah berlawanan pedestrian yang berupaya melakukan pelanggaran lalu lintas yaitu berupaya menabrakan diri, naum buktinya sangat kecil, dan sulit diperoleh elain dari adanya keterangan saksi yang meringankan sopir bus dan Ario pamungkas, diatur dalam dalam Pasal 183 KUHAP yaitu Hakim tidak boleh menjatuhkan pidana kepada seorang (sopir bus dan Rio pamungkas) kecuali dengan sekurang-kurangnya dengan adanya dua alat bukti yang sah.Di peroleh keyakinan bahwa suatu tindak pidana benar-benar terjadi dan bahwa terdakwalah yang bersalah melakukannya.

Syarat batas minimum pembuktian dalam persidangan tidak cukup berdasarkan keterangan saksi saja, namun pembuktian membutuhkan media alat bukti yang ditentukan dalam 184 KUHAP sebagai alat bukti di persidangan, kecuali jika ada rekaman CCTV yang dapat berintegrasi, bersinergis dengan alat bukti lain yang ditentukan dalam KUHAP.

Menurut Pasal 184 ayat (1) KUHAP keterangan saksi ahli adalah seorang ahli karena kapasitasnya sebagai ahli memiliki pengalaman dalam ilmu pengetahuan yang telah dipelajari (dimiliki)nya. Pengertian ilmu pengetahuan yang di tentukan sangat luas bersifat multi disipliner, sehingga van Bemmelen mengatakan bahwa ilmu tulisan, ilmu senjata, ilmu pengetahuan tentang sidik jari dan sebagainya termasuk dalam pengertian ilmu pengetahuan.

Menurut analisa penulis, keberadaan alat bukti petunjuk merupakan suatu pelengkap, karena penilaian atas kekuatan pembuktian, karena sifat dari alat bukti petunjuk merupakan alat bukti yang tidak langsung. Proses pembelaan pedestrian jika misalkan statusnya telah menjadi terdakwa, maka dalam pengadilan dibuktikan dengan adanya suatu testimony mengenai keterangan terdakwa yang diatur dalam Pasal 189 KUHAP, keterangan pedestrian yang lalai dalam menyeberang jalan sebagai terdakwa, menyatakan di sidang tentang perbuatan yang dialami dan diketahui sendiri. Alat bukti keterangan terdakwa (pedestrian yang lalai dalam menyeberang jalan sebagai terdakwa) hanya dapat digunakan terhadap dirinya sendiri dan harus didukung alat bukti lain untuk membuktikan 
pertangungjawaban atau tidak mempertanggungjawabkan pidana yang di dakwakan kepadanya.

Keterangan terdakwapedestrian yang lalai dalam menyeberang jalan sebagai sebagai alat bukti tidak perlu sama atau terbentur pengakuan.

\section{Penerapan Unsur Efektivitas Penegakan Hukum Terhadap Pejalan Kaki Dalam Perkara Kecelakaan Lalu Lintas Menurut Undang-Undang Republik Indonesia Nomor 22 Tahun 2009 Tentang Lalu Lintas dan Angkutan Jalan.}

Undang-undang Republik Indonesia Nomor 22 Tahun 2009 Tentang Lalu lintas dan angkutan Jalan mengatur unsur-unsur pasal pidana kecelakaan lalu lintas yang sifatnya kondisional, sifat kondisional ini menuntut aparat penegak hukum untuk bekerja lebih profesional dalam mengumpulkan alat bukti di lapangan. penyidik laka lantas sudah tidak dapat lagi menerapkan unsur pasal kecelakaan lalu lintas dengan cara konvensional, karena dengan cara ini penyidik lakalantas sulit menemukan kausalitas antara barang bukti dan saksi yang ada di TKP. Penyidik harus dapat menggambarkan kronologis kecelakaan lalu lintas dengan berdasarkan saksi dan bukti untuk menemukan unsur kesalahan dari pedestrian yang menyebrang di jalan, jadi tidak serta merta penyidik harus selalu mengkriminalisasikan pengendara saja dalam perkara kecelakaan lalu lintas.

Analisa penyidik mengenai penyebab pedestrian yang menyeberang jalan hingga terjadinya kecelakaan lalu lintas harus searah dengan unsur perbuatan pidana. Ada dua pasal pidana yang mengriminalisasi pengendara sebagai pelaku tindak pidana lakalantas , yaitu Pasal 310 dan Pasal 311 UU LLAJ. Kedua pasal tersebut mengarah pada pengemudi sebagai penyebab terjadinya kecelakaan, akan tetapi ada perbedaan mendasar dari kedua pasal tersebut yaitu pada kelalaian dan kesengajaan. Kedua hal ini sangat menarik untuk di bahas karena sebagian besar penyidik, penyidik laka lantas kesulitan untuk menerapkan menginvestigasi dan membuktikan unsur kesengajaan dan atau kelalaian.Ada dua bentuk kealpaan pedestrian yang menyeberang jalan, yaitu: Tidak berhati-hati, danTidak menduga-duga akibat perbuatan itu.

Kealpaan (Culpa) pedestrian yang menyeberang jalan dalam arti luas berarti kesalahan pada umumnya sedangkan culpa dalam arti sempit yaitu bentuk kesalahan yang berupa kealpaan, sebagaimana halnya dengan kesengajaan mengenai kealpaan ini juga diterangkan dalam Kitab Undang-undang Hukum Pidana (KUHP) tentang culpa.Definisi dari Van hamel bahwa, kealpaan mengandung dua syarat yaitu:Pedestrian yang menyeberang jalan tidak mengadakan penduga-duga sebagaimana diharuskan oleh hukum dan,Pedestrian yang menyeberang jalan tidak berhati-hati sebagaimana diharuskan oleh hukum.

Delik culpa pedestrian yang menyeberang jalan memiliki sifat melawan hukum dan telah tersimpul dalam culpa itu sendiri, pada umumnya culpa dibedakan atas kealpaan dengan kesadaran (bewuste schuld) dalam hal ini, pedestrian yang menyeberang jalan telah membayangkan atau menduka akan timbulnya suatu akibat, tetapi walaupun ia berusaha untuk mencegah, tetap timbul akibatnya.

Berdasarkan uraian di atas tampak jelas bahwa faktor subjektif pedestrian yang menyeberang jalan atau kehendak pelaku yang membedakanya adalah faktor kehendak yang pada pembuat mulai dari kehendak sebagai maksud sampai pada kealpaan keadaan faktor kehendak akan semakin lemah, penggunaan SI dalam mengidentifikasi adanya faktor kelalaian dapat dibuktikan dengan adanya camera CCTV dan atau jika tidak ada bukti CCTV penyidik akan mengolah TKP sesaat setelah terjadi kecelakaan.

Perkara kecelakaan lalu lintas yang dialami oleh sopir bus dan Ario Pamungkas membuktikan tingkat kelalaian tersangka Ario pamungkas dan Sopir bus menurut Undang- 
undang Republik Indonesia Nomor 22 Tahun 2009 Tentang Lalu Lintas dan Angkutan Jalan (UU LLAJ), Pasal 310 ayat (1) mengatur mengenai setiap orang yang mengemudikan kendaraan bermotor yang karena kelalaiannya mengakibatkan kecelakaan lalu lintas dengan kerusakan kendaraan dan/atau barang sebagaimana dimaksud dalam Pasal 229 ayat (2).

Ario Pamungkas dan sopir bus sebagai pengendara yang tidak sepatutnya dapat dipersalahkan sepenuhnya, namun ada faktor lain dari lalainya pedestrian yang menyeberang jalan. UULLAJ telah merumuskan unsur pidana untuk pedestrian yang menyeberang jalan, keterangan sebagai alat bukti (Pasal 185 ayat (1), namun keterangan saksi ini akan dipertanyakan jika KASAT kecelakaan Lalu Lintas harus saksi di hadirkan untuk menjelaskan mengenai kondisi kelalaian pedestrian yang menyeberang jalan, seperti perkara Ario pamungkas dan Sopir Bus. tentu saja hal ini merupakan suatu keterangan yang akan dipertanyakan kebenaran kelalaian pedestrian yang menyeberang jalan melalui :Jika pedestrian yang menyeberang jalan dalam keadaan mabuk dapat dianalisa oleh dokter, melalui tes urine dan lain sebagainya. Dan Perihal terjadinya kecelakaan tunggal yang tidak ditemukannya saksi alat bukti apapun di TKP, maka penyidik tidak boleh serta merta menerapkan Pasal 310311 UU lalulintas.

Kepolisian merupakan suatu alat bantu untuk memperjelas, membuat terang benderang dalam menerapkan unsur pidana yang diatur dalam Undang-undang LLAJ, yaitu apakah pedestrian yang menyeberang jalan lalai atau sengaja dalam pandangan Pasal 310 dan Pasal 311, barang bukti dan alat bukti telah sesuai dan dapat diterima oleh Jaksa Penuntut Umum.

Penerapan Unsur Penegakan Hukum Terhadap Pejalan Kaki (pedestrian) harus sejalan dan sesuai dengan profesionalisme POLRI, tanpa adanya kriminalisasi terhadap pedestrian, maka aparat penegak hukum KASAT kecelakaan Lalu Lintas berdasar undang undang Nomor 8 tahun 1981 tentang KUHAP maka, berkoordinasi secara maksimal dengan Puslabfor dalam proses penyidikan tindak pidana kecelakaan lalu lintas , mengingat Pasal 7 ayat (1) huruf h KUHAP yang menyatakan bahwa penyidik berwenang mendatangkan orang ahli yang diperlukan dalam hubungannya dengan pemeriksaan perkara, Pasal 120 ayat (1) KUHAP menyatakan dalam hal penyidik menganggap perlu, dapat minta pendapat orang ahli atau orang yang memiliki keahlian khusus.

Definisi tentang ahli dapat dilihat pada Pasal 1 butir 28 dan pada bagian penjelasan yang mengatakan bahwa yang dimaksud dengan ahli adalah seseorang yang karena keahliannya baik berdasarkan pendidikan atau pengalamannya memiliki keahlian dalam bidangnya.

Ketentuan Pasal 183 ketika penyidik akan menentukan status seseorang menjadi tersangka, sekurang-kurangnya harus dipenuhi dua alat bukti yang sah, sedangkan alat bukti yang sah sesuai Pasal 184 adalah keterangan saksi, keterangan ahli, surat, petunjuk, dan keterangan terdakwa. Sesuai tugas pokok dan fungsinya maka Puslabfor Bareskrim Polri dapat berperan dalam hal tersebut sebagai saksi ahli, memberikan alat bukti surat dalam bentuk berita acara pemeriksaan serta memberikan petunjuk sesuai hasil pemeriksaan yang berkaitan dengan tindak pidana yang terjadi mulai semenjak awal penyelidikan, penyidikan, penuntutan serta di pengadilan.

Upaya mencari dan mengumpulkan bukti dalam proses penyidikan, penyidik Kecelakaan lalu lintas diberi kewenangan seperti yang tersirat dalam Pasal 7 ayat (1) huruf h KUHAP yang menyatakan bahwa mendatangkan orang ahli yang diperlukan dalam hubungannya dengan pemeriksaan perkara dan Pasal 120 ayat (1) KUHAP menyatakan dalam hal penyidik menganggap perlu, ia dapat minta pendapat orang ahli atau orang yang memiliki keahlian khusus. 
Pengertian mendatangkan para ahli / memiliki keahlian khusus tersebut salah satunya dapat dipenuhi oleh Laboratorium Forensik, sehingga Laboratorium Forensik dapat berperan dalam tiap tahapan proses penegakan hukum yaitu : Tahap penyelidikanPada proses penyelidikan, penyelidik mempunyai wewenang untuk mencari keterangan dan barang bukti di TKP. Dalam rangka penanganan TKP ini, penyelidik maupun penyidik berusaha mencari barang bukti yang nantinya akan dilakukan pemeriksaan di Laboratorium. Untuk mengenali, mencari, mengambil dan mengumpulkan barang bukti tersebut diperlukan ketelitian, kecermatan dan pengetahuan atau keahlian mengenai bahan atau barang bukti tersebut. Oleh karena itu, tahap ini perlu melibatkan Laboratorium Forensik. Sebagai contoh kasus narkotika, pemalsuan produk industri, kebakaran, pembunuhan, peledakan, pencemaran lingkungan hidup / limbah dimana barang buktinya sering bersifat mikro yang keberhasilan penemuan dan pemeriksaan sangat tergantung terhadap teknologi yang dipergunakan. Dari hasil pemeriksaan laboratorium tersebut nantinya dapat dijadikan petunjuk dalam proses penyelidikan / penyidikan lebih lanjut. ${ }^{12}$

Tahap penindakan salah satu kegiatan penindakan adalah melakukan penyitaan terhadap barang atau benda yang ada hubungannya dengan tindak pidana yang terjadi. Dalam hal melakukan penyitaan terhadap benda atau barang yang berbahaya atau mudah terkontaminasi, cara pengambilannya memerlukan peralatan atau penanganan khusus, maka diperlukan dukungan teknis dari Laboratorium Forensik untuk menangani barang bukti tersebut. Sebagai contoh kasus pencemaran lingkungan, keracunan, kebakaran dan sebagainya. Dengan demikian, diharapkan bahwa barang bukti yang kemudian hari akan dilakukan pemeriksaan di Laboratorium tidak mengalami perubahan atau terkontaminasi, sehingga hasil pemeriksaan yang dilakukan akan sesuai dengan sifat asli barang bukti tersebut. Peran Laboratorium Forensik pada tahap penindakan sangat diperlukan yaitu pada pengambilan barang bukti atau sampling serta pengamanan atau pengawetan barang bukti yang akan diperiksa di laboratorium.

Tahap pemeriksaan Pemeriksaan merupakan kegiatan untuk mendapatkan keterangan, kejelasan dan keidentikkan tersangka dan atau saksi atau barang bukti, sehingga kedudukan atau peranan seseorang maupun barang bukti di dalam tindak pidana tersebut menjadi jelas. Salah satu kegiatan pada tahap pemeriksaan yang berhubungan dengan Laboratorium Forensik antara lain bahwa penyidik dapat meminta pendapat orang Ahli atau orang yang memiliki keahlian khusus. Sepanjang pendapat orang Ahli yang diminta penyidik tersebut berhubungan dengan barang bukti, maka Ahli tersebut akanmelakukan pemeriksaan atau analisa barang bukti di laboratorium. Sebagai contoh pemeriksaan kandungan zat aktif dalam narkotika, pemeriksaan racun dalam organ tubuh, pemeriksaan keaslian tulisan tangan, sidik jari pada senjata api dan sebagainya. Dimana hal-hal tersebut memerlukan pemanfaatan teknologi yang dimiliki oleh Laboratorium Forensik.

Tahap penyelesaian dan penyerahan berkas perkara.Tahap ini merupakan tahap akhir dari proses penyidikan. Dimana dalam hal penyidik telah selesai melakukan penyidikan, maka penyidik wajib segera menyerahkan berkas perkara itu kepada Penuntut Umum.Susunan berkas perkara, antara lain Berita Acara Pemeriksaan Ahli mengenai barang bukti.Dengan demikian, maka peran Laboratorium Forensik pada tahap ini adalah melakukan pembuatan Berita Acara Pemeriksaan Laboratoris Kriminalistik dan menyerahkannya kepada penyidik.

\footnotetext{
${ }^{12}$ Brigjen Polisi Andayo, Disampaikan pada Workhop Pengolahan TKP, di hotel Borobudur 21 Desember 2011, tentang Peran Pslabfor Bareskrim PolriDalam Rangka Scientific Investigation
} 
Tahap penuntutan Peran Laboratorium Forensik Polri dalam hal proses penuntutan, Penuntut Umum dapat melakukan konsultasi dengan pemeriksa Ahli dari Laboratorium Forensik tentang hasil pemeriksaan laboratoris kriminalistik, sehingga unsur pidana yang didakwakan kepada tersangka menjadi lebih akurat. Selain itu, dalam hal Jaksa melakukan penyidikan kasus tindak pidana khusus, maka jaksa sebagai penyidik dapat mengirimkan barang bukti untuk diperiksa oleh Ahli di Laboratorium Forensik.

\section{PENUTUP}

\section{Kesimpulan}

Pejalan Kaki Tidak Dapat Dipidana Dalam Perkara Tindak Pidana Kecelakaan Lalu Lintas Menurut Undang-Undang Nomor 22 Tahun 2009 Tentang Lalu Lintas dan Angkutan Jalan, Penyidik kepolisian dalam melakukan investigasi alat bukti perkara kecelakaan lalu lintas dengan objek terperiksa pedestrian lalai dalam kondisi menyeberang jalan, menurut norma tentang penetapan dan pembatalan, tindakan pedestrian yang lalai dalam menyeberang jalan yang bebas dari sistem moralitas dan norma sejenis lainnya. Hal ini membedakan antara hukum pidana dengan norma etika berlalu lintas dianggap sebagai pelanggaran, baik itu melanggar norma berprilaku (etika) atau norma kebiasaan berlalu lintas di suatu daerah.

Penerapan Unsur Penegakan Hukum Terhadap Pejalan Kaki dalam perkara kecelakaan lalu lintas menurut Menurut Undang-Undang Nomor 22 Tahun 2009 Tentang Lalu Lintas dan Angkutan Jalan dapat dilakukan kepolisian, namun terkendala dalam proses investigasi dalam mencari alat bukti, terutama barang bukti, saksi dapat diperoleh, namun barang bukti sangat sulit diperoleh, karena tata cara investigasi kepolisian secara konvensional masih menggunakan millimeter blok dalam Olah TKP.

\section{Saran}

Substansi hukum yang menyangkut new legal reform, pola kehendak perilaku masyarakat yang ada dalam sistem hukum tersebut. Rancangan Kitab Undang-undang Hukum Pidana (RKUHP) dan Rancangan Kitab Undang-undang Hukum acara Pidana (RKUHAP), yang sekarang berada dalam proses di lembaga departemen hukum dan Ham, diharapkan mampu mengubah tata cara penyelidikan khususnya kecelakaan lalu lintas.

Menyarankan agar penggunaan investigasi alat bukti kecelakaan lalu lintas yang dihasilkan oleh cara konvesnsional, yang dimulai dari penyelidikan hingga putusan persidangan. Hal ini terjadi karena tata cara investigasi pencarian bukti dengan cara konvensional sudah tidak sesuai lagi dengan hadirnya UU LLAJ dan KUHAP. 


\section{DAFTAR PUSTAKA}

Andi Hamzah, Asas-asas Hukum Pidana, PT. Rineka Cipta, Jakarta, 2008.

Dudu Duswara Machmudin, Pengantar Ilmu Hukum (Sebuah Sketsa), PT. Refika Aditama,Cetakan Keenam, Bandung, 2017

Irfan Fachruddin, Pengawasan Peradilan Administrasi terhadap tindak pemerintah, Alumni, Bandung,2004.

Leden Marpaung, Asas - Teori - Praktik Hukum Pidana, Sinar Grafika, Jakarta, 2009.

Moeljatno, Asas-asas Hukum Pidana. Bina Aksara, Jakarta, 1987

R. Subekti, Hukum Pembuktian,Jakarta, PT. Pradnya Paramita, 2007.

Romli Atmasasmita,Teori Hukum Integratif,Rekontruksi Terhadap Teori Hukum Pembangunan dan Teori Hukum Progresif, Genta Publishing, Yogyakarta, Cetakan Pertama, Maret 2012,

Soejono Soekanto, Polisi dan Lalu Lintas, Analisa Menurut Sosiologi Hukum, Mandar Maju, 1986.

Artikel ini telah tayang di Wartakotalive dengan judul Mahasiswa yang Mengendarai Motor-Sport-Asal-Depok-Tewas-Kecelakaan-Saat-Hindari-Penyeberang-Jalan- http: // wartakota. tribunnews.com/2018/09/25/mahasiswa- yang - mengendarai - motor sport - asal -depok-tewas-kecelakaan-saat-hindari-penyeberang-jalan. Penulis: Budi Sam - Law - Malau Editor: Gede Moenanto, diunduh pada tanggal 30 Maret 2019 pukul $9.11 \mathrm{wib}$

Putusan Pengadilan Negeri Sleman Nomor: 345/Pid.Sus/2014/PN.SMN, di ulas dalam www.hukum Online https://www.hukumonline.com/klinik/detail/lt570bf43a2e1ba/menabrak-pejalankaki-yang-menyeberang-tiba-tiba--bisakah-dituntut, diunduh pada tanggal 30 Maret 2019 pada pukul 08.00 wib.

Putusan Mahkamah Konstitusi Nomor 57/PUU-X/2012 terkait pengujian Undang-Undang Nomor 22 Tahun 2009 tentang Lalu Lintas dan Angkutan Jalan terhadap UndangUndang Dasar Negara Republik Indonesia Tahun 1945, yang diajukan oleh pemohon (Saipul Jamil).

Dirjen Penataan Ruang, Pedoman Penyediaan dan Pemanfaatan Prasarana dan Sarana Ruang Pejalan Kaki di Perkotaan,2000Dirjen Bina Marga,Tata Cara Perencanaan Jembatan Penyeberangan Untuk Pejalan Kaki di Perkotaan, 1995

TRL-UK/Institute of Road Engineering, 1997, Accident Costs in Indonesia. Road Research Development Project, Report No. RRDP 17, Agency for Research and Development, Bandung, Indonesia, hlm.

https://www.harapanrakyat.com/2019/03/seorang-pria-di-ciamis-tewas-nekad-menabrakandiri-ke -bus-yang-sedang-melaju/

Brigjen Polisi Andayo, Disampaikan pada Workhop Pengolahan TKP, di hotel Borobudur 21 Desember 2011, tentang Peran Pslabfor Bareskrim Polri Dalam Rangka Scientific Investigation

https://ferli1982.wordpress.com/2013/10/18/pembuktian-ilmiah-dalam-penanganan-lakalantas/ diunduh pada tanggal 8 Oktober 2016 pada pukul 21.45 